\section{BIBLIOGRAPHY}

ASPERGER, H. (1932), Arch. f. kinderheilk., 97, 167. BEHREND, G. (1880), Ibid., $1,138$.

BELL, D., and WOODS, A. W. (1942), Arch. Dis. Childh., 17, 157. CASPARY, J. (1884), Arch. Dermat u. Syph., 16, 122.

FERRI, U. (1928), La Pediatria, 36, 843.

GOEDHART, C. (1930), Nederl. Tijdschr. $v$. geneesk., 74, 5147. GOVAN, C. D., COTTỎN, A. L., and RYDEEN, J. O.'(1950), U.S. Armed Forces M.尹., x, 682 .

HALLEZ, G.-L. (1932), Nourrisson, 20, 270.

KAPOSI, M. (1887) cit. Govan et al.

LEINER, C. (1929), Monatschr. f. kinderheilk., 62, 331.

MACGILLIVRAY, A. G. (1942), Brit. med. F., ii, 340.

RITTER vON RITTERSHAIN, G. (1878), Centralzt.f. kinderheilk., 2, 3
RITTER VON RITTERSHAIN, G. (1880), Arch. kinderheilk., r, 53.

SANO, M. E. (1943), F. Pediat., 23, 280.

SCHWARTZMAN, J., DRAGULSKY, D., and ROOK, G. (1941), Am. F. Dis. Child., 62, 352.

SKINNER, E. F. (1910), Arch. Dermat. and Syph., 22, 75.

vaN VONNO, N. C. (193I), Nederl. Tijdschr. v. geneesk., 75, 1932.

WARTHEN, R. O., and SHERBURNE, J. C. (1948), ₹. Pediat., 3B, 717 .

WIDERMAN, A. (1945), Am. F. Dis. Child., 70, 329.

WIELAND, E. (1923), Ergeb. d. Inneren Med. u. kinderheilk., 24, 47. WIENER, A. S. (1947), New York St. M.Ұ., 47, 1796. WINTERNITZ, R. (1898), Arch. Dermat. u. Syph., 44, 397.

ZAKON, S. J. (1931), Arch. Dermat. and Syph., 24, 830.

\title{
THE POSTGRADUATE
}
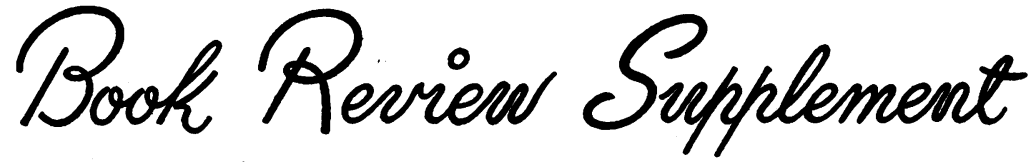

\section{CHEMICAL INDUCTION OF CANCER}

By George Wolf, B.Sc., D.Phil. Pp. xiii +250 , with 5 illustrations. London: Cassel \& Co., Ltd., 1952. 17s. 6d.

This is a book which, as the title indicates, deals with the experimental production of cancer by purely chemical means, i.e., through the intervention of chemical compounds of, for the most part, known chemical constitution whose chemical formulae are depicted. To the discerning chemist with an eye to equating chemical constitution with carcinogenic activity, the work is particularly appealing in the wealth of structural formulae scattered throughout its pages. The author has succeeded in surveying the subject in a comprehensive, authoritative and not over-elaborate way, so that the result is a short and lucid presentation of the facts.

There are five main sections; the structure and activity of tumour-inducing compounds; the biological aspects of tumour induction, as seen in tumour characteristics and pathology, sex differences, hereditary differences, species differences, age and diet; test methods, notably the mode of administration, dosage, latent period, tumour incidence and carcinogenic index; theories of the mode of action of cancinogens; biogenetic relationships; and a final section on the metabolism of carcinogenic hydrocarbons, azo-compounds, aromatic amines and derivatives.

The book is indexed both according to authors and subject matter, thereby facilitating reference. While appealing perhaps specially to the research worker, the thoughtful information packed in the pages of the book will make it fascinating alike to the interested doctor and the enlightened layman. As Professor Haddow puts it, the book will be ' welcomed by those wishing to acquaint themselveso without too great difficulty, with a field of research which, if it has of necessity developed along highlo specialized lines, is nevertheless of the utmost im? portance towards the ultimate solution of the greatest problem confronting medicine.'

The book is attractive in presentation and written in a clear and easily comprehensible style. Moreover, it is moderately priced.

A.C.

\section{THE STORY OF THE ADAPTATION SYNDROME}

By Hans Selye, M.D., Ph.D., D.Sc., F.R.S.(C.)• Pp. 225, illustrated. Montreal: Acta Inc. Medical Publishers. 1952. \$4.50.

Professor Selye tells in this volume how he conceived the idea that a group of apparently unrelated physiological changes, evoked by a variety of stimuli, were part of a common response which he has called the General Adaptation Syndrome. He tells, also, how he has come to believe that a relationship exists between this common response and a variety of diseases in man. The author truly states that in this volume there is no pretence either at objectivity or at completeness. Because of this, and the avowedly informal style, the book cannot be recommended to those wishing seriously to appraise Professor Selye's hypotheses. It provides, however, an easy means whereby the uninitiated may approach the author's larger work with its 8,000 odd references. 